\title{
Students' Perceptions and Attitudes Toward the Use of Communicative Language Teaching (CLT) to Improve English Listening and Speaking Skills
}

\author{
Tinutda $\mathrm{Komol}^{1} \&$ Sasitorn Suwanphathama ${ }^{1}$ \\ ${ }^{1}$ Department of foreign languages, Rajamangala University of Technology Srivijaya, Songkla, Thailand \\ Correspondence: Tinutda Komol, Department of Foreign Languages, Rajamangala University of Technology \\ Srivijaya, Songkhla, 90000, Thailand. E-mail: tinutda_k@yahoo.com
}

Received: August 15, 2020 Accepted: November 3, 2020 Online Published: November 13, 2020

doi:10.5539/ells.v10n4p40 URL: https://doi.org/10.5539/ells.v10n4p40

\begin{abstract}
This study aimed to investigate the students' perceptions and attitudes toward the use of communicative language teaching to improve their English listening and speaking skills. 82 fourth-year students who enrolled in English in Media course were asked to give their perceptions and attitudes in learning from communicative language teaching (e.g., role-play, pair work, group work, group discussion and making a video). The Results showed that the students had strong positive perception toward the classroom activities suggested by the communicative teaching approach. It is suggested that using role-play, group discussion and video production can help increase the students' confidence and improve their listening and speaking skills. Moreover, the students also strongly agreed that making an English short movie video allowed them to get much exposure to using English.
\end{abstract}

Keywords: communicative language teaching, perceptions, attitudes, listening and speaking skills

\section{Introduction}

\subsection{Background of the Study}

In Thailand, English language classroom heavily focused on the grammatical component of the language. Often, students are asked to practice to master language rules and read from the textbooks. As the result, students have shown low proficiency in speaking even though they have good knowledge in vocabulary, grammar, and reading skill. Students' communicative ability has become a concern because many students do not show satisfying levels of proficiency in communication even after ten years of English language Learning. Ellis (1997) noted that second and foreign language acquisition is a complex, multifaceted phenomenon and it is not surprising that it has come to mean different thing to different people.

As part of the education reform process, the Thai government is pressing universities throughout Thailand to emphasize the importance of English speaking for Thai students; the government has highlighted that more useful activities should be introduced into language classroom and it is important that the instructors use English as a medium in class to help the students to get familiar with English since they only learn English in the classroom. They are less exposed to English in their daily life. Moreover, research on the topic of needs and wants of English in workplaces has also suggested that the English curriculum in Thai universities does not meet the demands for English used in the workplace. The skills used most at this level are listening and speaking, which are not sufficiently focused on the Thai tertiary curriculum for the teaching of English.

\subsection{Importance of the Problem}

In the past decade, Thai teachers used traditional teaching method in language classrooms. This may lead to the students' lack of practice in listening and speaking in authentic situations and the use of authentic materials. Effective teaching methods have been sought to help improve the teaching and learning English in classroom in Thai context. Communicative approach is becoming one of the preferred methods among English language teachers. If teachers are going to employ communicative language teaching as a teaching method, they need to empower that method of learning for the students, not just giving a lecture. It is possible that teachers want students to work with authentic language materials, and to verify their language competence through some kind 
of testing and feedback. Teachers want students to interact with others, use the language for real communication (not just in staged classroom scenarios), and learn from one another. This means that teachers have to provide the interaction activities and to give students with opportunities to use the language outside classroom. Teachers need to use communicative language teaching (CLT) to supplement what they do in the classroom and to help students in doing what they are not able to do very well. Teachers also need to use this method of teaching to encourage them to think beyond the traditional approach and to experiment with approaches they have not previously considered.

In recent years, teachers in Thailand have tried to adopt theories and methods of communicative language teaching (CLT) in their classroom. This teaching method was introduced in 1970s and is regarded as one of the most effective approaches to language teaching (Chang, 2011), and still remains a popular approach for teaching English in many countries. In the first semester of 2014 academic year at Rajamagala University of Technology Srivijaya, communicative language teaching (CLT) was used to help language leaning for the students who enrolled in the "English in Media" course. This course is designed for students to learn about the use of the English language (both text and dialogue) in media such as learning English from movies, songs, magazines, dramas. Communicative teaching approach was relied on and a variety of language interactive activities were designed and implemented in class to improve the students' listening and speaking skills. The students learn English through many interactive activities and there are more tasks for them to perform in class. For example, they do not only learn a variety of conversational topics, but also do role-play based on the topics they have already learned. This research aimed to establish what learners' attitudes and perceptions were toward the use of the communicative language teaching to improve listening and speaking skills and whether or not the teachers would continue to use the communicative language teaching approach.

\section{Literature Review}

\subsection{Communicative Language Teaching Approach}

The main reason why communicative activities should be integrated in the lesson is that all people need to communicate in order to share ideas, thoughts, and feelings. Students can speak language effectively when they are engaged in a variety of learning environments that help them to do their tasks. Many researchers (Breen \& Canlin, 1980; Brown \& Yule, 1983; Candlin, 1976; Hymes, 1972; Richards, 2006; Moss \& Ross-Feldman, 2003; Jeyasala, 2014) have studied how students improve their English communicative skills. Researchers agreed that in order to develop the students' communicative competence they need to be engaged in English communicative activities so that they are involved themselves in the real situations.

According to Moss and Ross-Feldman (2003), learners can develop their speaking and listening skills through communicative activities because they can find more information, and express ideas about themselves. To encourage the students to speak English more fluently and accurately, they should be provided with real communicative contexts. This way, the students can share real information, express feelings and learn about culture of target language. Jeyasala (2014) suggests that teachers should provide the students with space to interact with others or to convince them in speaking tasks that help them to use the target language. By using the speaking tasks, the teachers can enhance student's communicative competence as much as possible and can help them use language fluently and accurately.

Brown and Yule (1983) support that the trend of English teaching is to focus on meaning, not only form of the language. Candline (1976) also notes that teachers need to understand meaning rather than just grammatical structure. Richard (2006) points out that learning language does not guarantee that the learner will be able to use the language fluently and accurately. The reason can be the lack of strategies to focus on meaning, not only form of the language in communicative actives. Hence, learners should be engaged and confident to express their ideas. It does not matter whether they use language properly, but they have to try to improve their language skills through frequently practicing.

In short, communicative teaching is the standard approach of target language involving the following aspects of language knowledge: knowing how to vary the use of the language, knowing how to use language in a variety of contexts, comprehending different types of texts, and being able to communicate language despite any limitation the speaker may have.

\subsection{Promoting Interaction in the English Classroom by Applying the Appropriate Teaching Materials}

Interaction plays a significant role in language learning as it provides the students the opportunity to practice their communication skills. Richards (2001) points out that materials, such as textbooks, materials provided by the institution or materials provided by teachers are the important element in language learning (as cited in 
McGrath, 2013). To facilitate interaction among learners, the materials have to be carefully chosen. Schiffrin (1996) states that traditional books give insufficient content of language learning and do not provide enough communicative input (as cited in Peacock, 1997).

One of the best ways to provide an opportunity for the students to be more communicatively competent is to provide an authentic environment which can encourage this outcome. The technological tools, such as TV, films, or the Internet, are the key elements in language learning since they can provide a variety of contextual inputs that traditional textbooks cannot (Cummings, 1994). Vlatten (1997) states that using videos in language classroom can help students get familiar with authentic voices and different accents that provide them with cultural-related aspects of langauge (as cited in Salaberry, 2001). According to Yukselir and Komur (2017), a proper way to develop the student's communicative competence is to use online videos in the classroom.

Moreover, Peacock (1997) notes that a lot of authors believe that authentic materials should be used in language teaching to motivate learners in foreign language learning. They also believe that the use of authentic materials is more interesting and motivating than non-authentic materials.

\subsection{Foreign Language Learners' Attitudes and Perceptions}

Attitude is one of aspects which affect students' communicative language learning and their language competency. Not many studies have investigated learners' attitudes and perceptions. Schulz (1996) notes that leaners' learning attitudes should not be ignored, especially when teachers' points of view and those of the learners are different. Brown (2007) states that attitude is the same on all factors of development of cognition and affect in human life. People's attitude can develop from the early childhood period which is the result of their parents' envelopment and friends' influence that finally bring either positive or negative value judgment.

McGroarty (1999) asserts that attitude of each person can be lined to values and beliefs and can be promoted or be discouraged the choices that made in all realms of activities, no matter academic or informal. Oskamp and Schultz (2005) define attitude as the habit of people to respond in like or dislike manners with respect to a given attitude to an object. Moreover, attitude can be seen directly rather than can be analyzed from particular behavior toward some class of objects, persons, event and issues in a period of time. Therefore, attitude can be defined as positive or negative feelings that a person holds about certain objects or ideas.

Few studies have investigated leaners' attitudes toward communicative language learning both at international and local levels. Arani (2004) conducted a study in Iran examining medical students' attitudes toward learning English. The result revealed that majority of the subjects had favorable attitudes. His study was in line with Soleimani and Hanafi's (2013) findings which described that Iranian medical students had highly positive attitudes toward English language learning. Yang (2010) studied about attitudes of Chinese students learning English through communicative approach. She found that college students held positive attitudes toward English language learning. Moreover, Rukh (2014) confirmed that business students had positive attitudes towards English language learning.

It can be concluded that communicative language learning plays a significant role in language learning and teaching as it involves students in their own learning. However, few studies have been done on the attitudes of students to communicative language learning as a way to improve English listening and speaking skills. It is the interest of the authors to investigate into this area to get pedagogically useful and in-dept information.

\section{Method}

\subsection{Research Questions}

The present study aimed at finding the answers to the following questions.

1) What are students' perceptions and attitudes on learning English listening and speaking skills through the communicative language teaching approach?

2) Are the students willing to continue learning through the communicative language teaching?

\subsection{Participants}

The participants of the study were 82 fourth year English major students in a Thai university. They were 22 males and 60 females whose age ranged from 20 to 22 years old. All of them have learned English as a foreign language for at least seven years.

\subsection{Instruments}

A questionnaire was used as the instrument in this study. There were 20 items in this questionnaire. The first part of the questionnaire asked about the students' perceptions toward communicative language teaching. The second 
part of this questionnaire was aimed at eliciting student's attitudes toward communicative language teaching (e.g., the use of role-play, group discussion activities and project work). The students were asked to rate the matters based on a five-point scale ranging from 5 (Strongly agree) to 1 (Strongly disagree).

\subsection{Data Collection}

Data collection procedure was conducted within 16 consecutive weeks. This was a period of three days per week of learning. The procedure involved asking students to participate in role-play activities, group discussion and project work.

After 16 weeks of the experimental period, the students were asked to complete the questionnaire concerning their attitudes and perceptions toward learning through the communicative language teaching (CLT) to improve English listening and speaking skills.

\section{Results and Discussion}

The results and discussion of the study are presented in accordance with the two research questions proposed earlier.

\subsection{Students' Perception of Communicative Teaching Activities}

Table 1. Students' perception toward the use of communicative language teaching

\begin{tabular}{|c|c|c|c|}
\hline Items & $\bar{X}$ & S.D. & Levels \\
\hline \multicolumn{4}{|l|}{ Part I: Perceptions toward communicative language teaching } \\
\hline 1. The role-play activities help me have confidence in speaking skill. & 4.36 & 0.71 & Strongly agree \\
\hline 2. The role-play activities allow me to be more creative. & 4.15 & 0.59 & Agree \\
\hline 3. The role-play activities allow me to be good at pronunciation. & 4.16 & 0.68 & Agree \\
\hline 4. The teacher's instruction on how to do class activities is necessary. & 4.02 & 0.59 & Agree \\
\hline 5. I think the group discussion activities allow me to learn speaking skills. & 4.26 & 0.68 & Strongly agree \\
\hline 6. I think group discussion helps me improve my listening skill. & 3.56 & 0.45 & Agree \\
\hline 7. I think making an English short movie video allows me to get much exposure of using English. & 4.50 & 0.65 & Strongly agree \\
\hline 8. The role of the teacher as a facilitator in the language classroom is very important. & 3.89 & 0.55 & Agree \\
\hline 9. Role-play, group discussion, and language video making help me to gain confidence in speaking. & 4.85 & 0.80 & Strongly agree \\
\hline 10. Role-play, group discussion, and making video help me have confidence in listening. & 4.70 & 0.75 & Strongly agree \\
\hline Total & 4.26 & 0.51 & Strongly agree \\
\hline
\end{tabular}

Table 1 illustrates the students' perceptions toward the use of communicative language teaching, as can be seen in this table, the total average score $(\bar{X}=4.26)$ showed that students were strongly positive toward the use communicative language teaching. Most of the students strongly agreed that role-play, group discussion, and making a video helped them to have confidence in speaking $(X=4.85)$, and to help them have more confidence in listening $(\bar{X}=4.70)$. They also strongly agreed that making an English short movie video and involving in group discussion allowed them to improve speaking English $(X=4.50)$, and got much exposure of using English $(\bar{X}=4.26)$. The students agreed that role-play activities allowed them to be good at pronunciation $(X=4.16)$ and helped them to be confident when speaking $(\bar{X}=4.36)$, the role-play activities allowed them to be more creative ( $\bar{X}=4.15)$, the teacher's instruction on how to do class activities was necessary $(\bar{X}=4.02)$, the role of the teacher as a facilitator in the language classroom is very important $(\bar{X}=3.89)$, and they think group discussion helped them to be good at listening $(\bar{X}=3.56)$. This result is consistent with the findings of Moss and Ross-Feldman (2003), Jeyasala (2014), which found that teachers should provide the students space to interact with others or to convince them to take part in speaking tasks. Also, the finding is in line with that of Li (1998), which indicated that the role of a teacher as a facilitator is important. 


\subsection{Students'Attitudes of Communicative Teaching Activities}

Table 2. Students' attitudes toward the use of communicative language teaching

\begin{tabular}{|c|c|c|c|}
\hline Items & $\bar{X}$ & S.D. & Levels \\
\hline \multicolumn{4}{|l|}{ Part II: Attitudes toward the Use of Communicative Language Teaching } \\
\hline 1. I think using role-play as a way to promote English speaking is useful method of learning English. & 4.26 & 0.68 & Strongly agree \\
\hline 2. I think using group discussion is very useful to help me to be more creative. & 4.02 & 0.59 & Agree \\
\hline 3. I hope that the teacher will implement this teaching method in other English classes. & 3.75 & 0.68 & Agree \\
\hline 4. I will use this communicative language learning to practice English in my own time. & 3.56 & 0.45 & Agree \\
\hline 5. Even though, this method takes me much time to practice by my own, I will continue using it. & 4.45 & 0.65 & Strongly agree \\
\hline $\begin{array}{l}\text { 6. Even though role-play activities take me a lot of time to recite lines of the dialogue, it helps me to } \\
\text { improve my speaking skill. }\end{array}$ & 4.59 & 0.55 & Strongly Agree \\
\hline $\begin{array}{l}\text { 7. Even though, role-play activities take me a lot of time to recite lines of the dialogue, it helps me to } \\
\text { improve my listening skill. }\end{array}$ & 4.88 & 0.80 & Strongly agree \\
\hline $\begin{array}{l}\text { 8. I hope that the teacher will assign the students in other English classes to make a video since it is very } \\
\text { useful for them to write their own English script as a way to improve English ability. }\end{array}$ & 4.18 & 0.75 & Agree \\
\hline 9. It takes me a long time to make a video but I really enjoyed doing it. & 4.69 & 0.51 & Strongly agree \\
\hline $\begin{array}{l}\text { 10. I can apply all activities for my other English subjects since those activities are very useful for me } \\
\text { to improve my English listening and speaking skills. }\end{array}$ & 4.90 & 0.61 & Strongly agree \\
\hline Total & 4.32 & 0.62 & Strongly agree \\
\hline
\end{tabular}

According to Table 2, the students strongly agreed with the effectiveness of the communicative language teaching activities ( $\bar{X}=4.32$ ). The students strongly agreed that they could apply all activities of communicative language teaching for their other English subjects since those activities were very useful to improve their English listening and speaking skills $(\bar{X}=4.90)$. They said that even though, role-play activities took them a lot of time to memorize lines of the dialogue, it helped them to improve their listening skill ( $\bar{X}=4.88)$ and even it took them a long time to make a video but they really enjoyed doing it $(\bar{X}=4.69)$. Moreover, they reported that even though role-play activities took them a lot of time to memorize lines of the dialogue, it helped them to improve their speaking skill $(\bar{X}=4.59)$ and this method took them much time to practice by their own, they wished to continue using it $(\bar{X}=4.45)$. They thought that doing role-play was a useful method to promote English speaking skill $(\bar{X}=4.26)$.

The students agreed that they wish the teacher will assign the students in other English classes to make a video since it was very useful for them to write their own English script as a way to improve English ability $(\bar{X}=4.18)$. They thought group discussion was a very useful method for helping them to be more creative $(\bar{X}=4.02)$. They hoped that teachers implement this teaching method for their other English classes $(\bar{X}=3.75)$. And the students agreed to continue using this communicative language learning to practice English learning $(\bar{X}=3.56)$.

The result of this study pointed that the majority of the students had positive attitudes towards communicative language learning, which was in line with the findings of Arani (2004), Yang (2010), Soleimani and Hanafi (2013), and Rukh (2014).

\section{Pedagogical Implications}

The findings of this study provide some pedagogical implications. Firstly, this study suggests that the teachers have an important role in modeling effective classroom activities to enhance learning environments. The students need to be conscious of using the classroom activities in learning English in order to gain the benefits from the effective classroom activities. Teachers should clearly demonstrate the students the reasons for implanting communicative language teaching (CLT), and how it helps the students. Secondly, the use of effective classroom activities is indeed a reality and will become increasingly important as language education is at the 21 st century. The possibility to completely replace the traditional classroom with communicative language teaching is still doubtful, but based on the finding of the current research, it is beneficial for ESL/EFL students to apply the useful activities to practice and learn English language in other classes. Thirdly, in order to be effective in applying the activities in the classroom, teachers must remove themselves from the classroom attention, and place the focus on the students. The very nature of the CLT is conductive to student-centered learning. Fourthly, according to the standards of the university curriculum set by the Thai ministry of Education, universities can take an important role as training institutes. One of the ministry's expectations is that university students will be able to communicate English fluently by learning through communicative language teaching (CLT) for their life-long learning. 


\section{Conclusion}

This descriptive study has illustrated the students' perceptions and attitudes toward the communicative teaching (CLT). The results of this study affirmed that students consider the CLT classroom activities useful as supplement in-class instruction. The students realized that it is appropriate to learn English language through this approach. They agreed that the large amount and a wide variety of classroom activities provided by the teachers can be used both for supplementing their class contents and for their self-study. The students also agreed that this CLT enhanced their confidence and improved both listening and speaking skills. The findings support Richards' (2001) notion about one of goals of CLT, which is to develop fluency in language use. Fluency is natural language use occurring when a speaker engages in meaningful interaction and maintains comprehensible and ongoing communication despite limitations in his or her communicative competence. Fluency is developed by creating classroom activities in which students must negotiate meaning, use communication strategies, correct misunderstanding, and work to avoid communication breakdowns.

\section{Acknowledgments}

The authors would like to pay special regards to Rajamangala University of Technology Srivijaya for the financial support. Without this support, the research would not have been completed. Our sincere thanks are also extended to the participants of the study and the reviewers of the article.

\section{References}

Arani, J. (2004). Attitudes towards learning English of medical students at Kashan University of Medical Sciences: Iran. Karan's Linguistics Issues. (Online) Retrieved from http://www3.telus.net/linguisticsissues/emp

Breen, M. P., \& Candlin, C. N. (1980). The essentials of a communicative curriculum in language teaching. Applied Linguistics, 1(2), 89-112. https://doi.org/10.1093/applin/I.2.89

Brown, G., \& Yule, G. (1983). Teaching the Spoken Language: An approach based on the analysis of conversational English. New York, NY: Cambridge University Press.

Brown, H. (2007). Principles of language learning and teaching (5th ed.). Pearson: Longman.

Candlin, C. N. (1976). Communicative language teaching and the debt to pragmatics. In C. Ramch (Ed.), Georgetown University Roundtable Bulletin (pp. 56, 81-105).

Chang, M. (2011). EFL Teachers' Attitudes toward Communicative Language Teaching in Taiwanese College. Asian EFL Journal, 53, 17-34.

Cummings, L, E. (1994). HyperNexus: Journal of hypermedia and multimedia studies. HyperNexus, 4(1-4).

Ellis, R. (1997). Second language acquisition. Oxford: Oxford University Press.

Hymes, D. (1972). On communicative competence. In J. B. Pride \& J. Holmes (Eds.), Sociolinguistics (pp. 269-293). Harmondsworth, England: Penguin.

Jeyasala, V. R. (2014). A prelude to practice: Interactive activities for effective communication in English (pp. 164-170). Alternative pedagogies in the English language \& communication classroom.

Li, D. (1998). It's always more difficult than you plan and imagine: Teachers' perceived difficulties in introducing the communicative approach in South Korea. TESOL Quarterly, 32(4), 677-703. https://doi.org/10.2307/3588000

McGrath, I. (2013). Teaching materials and the roles of EFL/ESL teacher: Practice and theory. New York: Bloomsbury Academic.

McGroarty, M. (1999). Language attitudes, motivation and standards. In S. L. McKay \& N. Hornberger (Eds.), Sociolinguistics and language teaching. Cambridge: CUP.

Moss, D., \& Ross-Feldman, L. (2003). Second language acquisition in adults: From research to practice. Retrieved from http://www.cal.org/CAELA/esl_resources/digests/SLA.html

Oskamp, S., \& Schultz, P. (2005). Attitudes and opinions. Mahwah, NJ: Lawrence Erlbaum. https://doi.org/10.4324/9781410611963

Peacock, M. (1997). The effect of authentic materials on the motivation of EFL learners. ELT Journal, 51(2), 144-156. https://doi.org/10.1093/elt/51.2.144

Richards, J. C. (2006). Communicative language teaching today. SEAMEO Regional Language Centre. 
Richards, J. C., \& Rodgers, T. S. (Eds.). (2001). Approaches and Methods in Language Teaching (2nd ed.). Cambridge: Cambridge University Press. https://doi.org/10.1017/CBO9780511667305

Rukh, S. (2014). Students' attitude towards English language learning and academic achievement: A Case of Business Students in Punjab. European Academic Research Journal, 2(4), 5596-5612. Retrieved from http://www.euacademic.org

Salaberry, R. (2001). The use of Technology for Second Language Learning and Teaching: A Retrospective. Modern Language Journal, 85(1), 39-56. https://doi.org/10.1111/0026-7902.00096

Soleimani, H., \& Hanafi, S. (2013). Iranian medical students' attitude towards English language learning. International Research Journal of Applied \& Basic Sciences, 4(1), 3816-3823.

Yang, Y. (2010). Attitudes of learners towards English: A case study of Chinese College students. Pro Quest LLC, $\mathrm{Ph} . D$. Dissertation, the Ohio State University

Yukselir, C., \& Komur, S. (2017), Using online videos to improve Speaking abilities of EFL Learner. European Journal of Education Studies, 4, 255-265.

\section{Copyrights}

Copyright for this article is retained by the author, with first publication rights granted to the journal.

This is an open-access article distributed under the terms and conditions of the Creative Commons Attribution license (http://creativecommons.org/licenses/by/4.0/). 